\title{
MEWUJUDKAN KEAMANAN INSANI DARI ANCAMAN NON- TRADISIONAL: PENCEGAHAN COVID-19 DI PASAR MINGGU DESA KOTA TENGAH
}

\author{
Luerdi, Rahmadi Khaidir, Novi Dian Sari Nasution, Widia Anggraini, Nabilah, \\ Muhammad Rozi Muharpan \\ Universitas Abdurrab, Indonesia \\ luerdi@univrab.ac.id
}

\begin{abstract}
This community service program aimed to realize human security from the threat of COVID-19 pandemy by conducting preventive attempts at the Pasar Minggu, Village of Kota Tengah, Subdistrict of Kepenuhan, District of Rokan Hulu. Insufficient literacy on the pandemic and very limited numbers of prevention facilities in the market encouraged the community service. The activitiy was carried out for more and less two weeks in the form of socializing and providing equipment. The program had a number of work plans such as informing the danger and threat of COVID-19, setting up a banner encouraging people to implement health protocol and providing public hand-washing facilities. Such program is expected to help to cut off the swift spread of COVID-19 among people in the non-urban areas especially those located in the Village of Kota Tengah.
\end{abstract}

Keywords: human security; COVID-19; prevention; Pasar Minggu

\begin{abstract}
Abstrak
Kegiatan pengabdian kepada masyarakat ini bertujuan untuk mewujudkan keamanan insani dari ancaman pandemi COVID-19 dengan cara melakukan upaya pencegahan penyebaran di Pasar Minggu Desa Kota Tengah Kecamatan Kepenuhan Kabupaten Rokan Hulu. Literasi masyarakat yang rendah tentang COVID-19 dan keterbatasan sarana pencegahan COVID-19 di lingkungan Pasar Minggu menjadi alasan utama kegiatan ini. Kegiatan ini dilaksanakan selama kurang lebih dua minggu dalam bentuk sosialisasi dan penyediaan sarana. Pengabdian ini memiliki beberapa rencana kerja seperti pemberian informasi tentang bahaya dan ancaman COVID-19, pemasangan spanduk ajakan penerapan protokol kesehatan dan pembuatan tempat pencuci tangan. Kegiatan ini diharapkan dapat membantu pemutusan penyebaran COVID-19 di daerah khususnya di Desa Kota Tengah.
\end{abstract}

Kata Kunci: keamanan insani; COVID-19; pencegahan; Pasar Minggu

Submitted: $2020-09-10$ Revised: 2020-09-22 Accepted: $2020-09-25$

\section{Pendahuluan}

Globalisasi yang didukung oleh perkembangan teknologi informasi dan transportasi telah menjadikan dunia seolah-olah tidak memiliki batas. Peristiwa yang terjadi pada satu negara akan meyebar dengan cepat di negara lain. Namun, globalisasi yang tak terhindari tersebut tidak hanya membawa perkembangan yang bermanfaat bagi negara lain, tapi juga membawa ancaman terhadap kemanan insani seperti wabah penyakit menular. Kini wabah penyakit menular semakin menjadi hirauan dari beragam ilmu baik ilmu alam ataupun ilmu sosial (Bainus \& Rahman, 2020:113).

Salah satu ancaman terhadap keamanan insani yang sedang dihadapi oleh seluruh negara dan entitas internasional lainnya adalah pandemi Novel Coronovirus Disease (COVID-19). COVID-19 merupakan penyakit menular yang mengganggu sistem 
pernapasan yang disebabkan oleh varian virus Corona baru (SARS-COV-2). Penyakit tersebut pertama kali dilaporkan muncul di Wuhan, Republik Rakyat Tiongkok pada 31 Desember 2019 dan dinyatakan sebagai pandemi oleh World Health Organization (WHO) pada 11 Maret 2020 (World Health Organization, 2020; Djalante at al., 2020:1). Menjelang akhir April 2020, pandemi tersebut telah menyebar ke lebih 200 negara (Lebni at al., 2020:1).

Untuk mencegah penyebaran COVID-19 di Indonesia, Pemerintah Indonesia telah memberikan izin kepada beberapa pemerintah daerah untuk menerapkan kebijakan Pembatasan Sosial Berskala Besar (PSBB) ketimbang Karantina Wilayah menjelang akhir Maret 2020 (Setiati \& Azwar, 2020:85). Memasuki Kebiasaan Baru (New Normal), Pemerintah Indonesia menghimbau masyarakat untuk mematuhi protokol kesehatan yang dianjurkan seperti memakai masker, menjaga jarak dan sering mencuci tangan pakai sabun. Namun, Indonesia tetap menjadi salah satu negara yang mengalami kasus COVID19 yang tertinggi di Asia Tenggara dan bahkan, jumlahnya semakin meningkat setelah kebijakan PSBB dihentikan di banyak daerah atau sejak diberlakukannya Kebiasaan Baru.

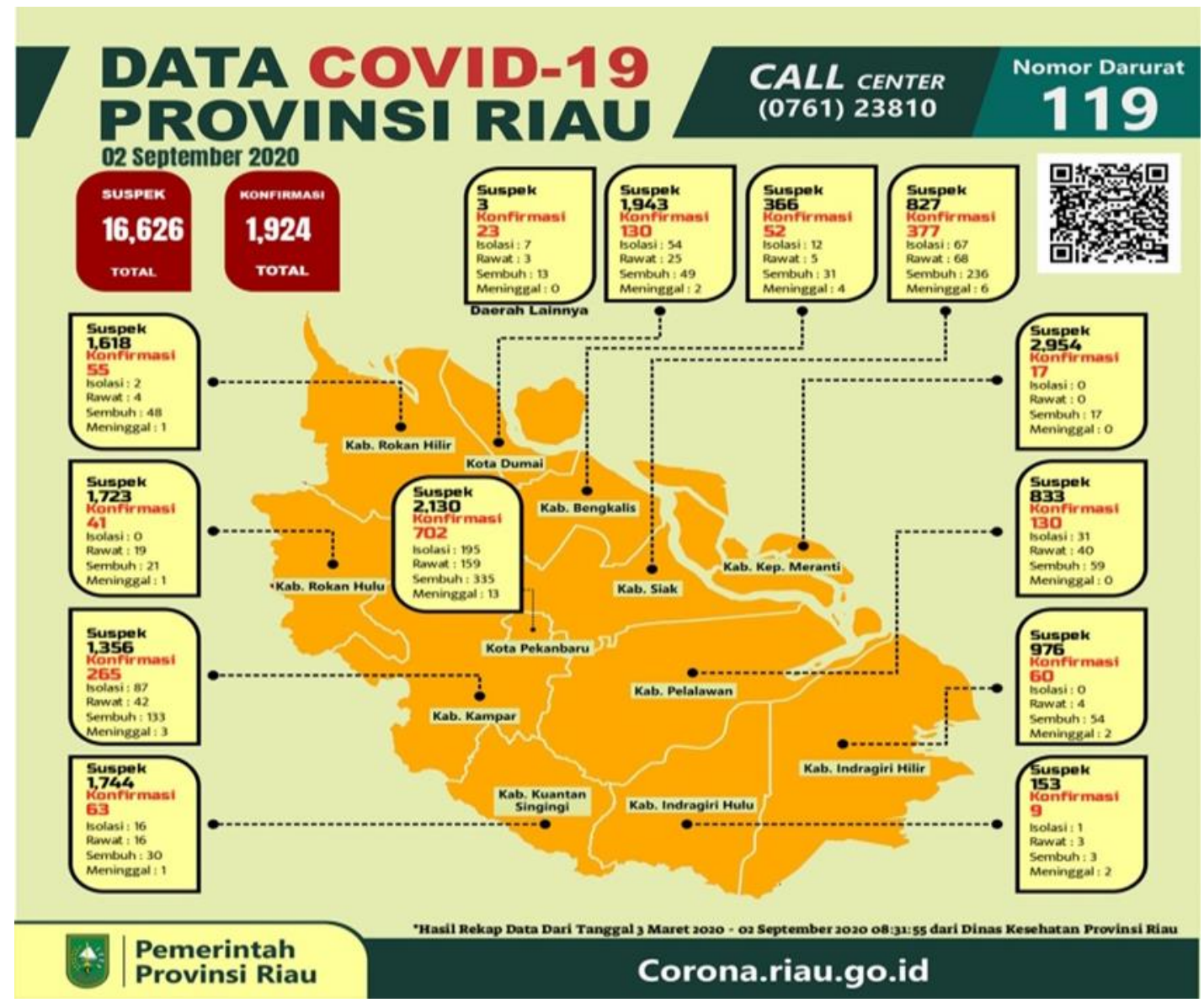

Gambar 1. Data COVID-19 Provinsi Riau (Riau Tanggap COVID-19, t.t.)

Per tanggal 2 September 2020, telah tercatat sebanyak 177.523 kasus positif COVID-19 dan sebanyak 7.505 kasus pasien COVID-19 yang meninggal di Indonesia (Gugus Tugas Nasional Percepatan Penanganan COVID-19, t.t). Untuk Propinsi Riau, 
tercatat 1.924 kasus positif COVID-19 dan 25 kasus meninggal akibat COVID-19 seperti yang terlihat pada gambar 1 (Riau Tanggap COVID-19, t.t).

Dari informasi pada gambar 1, COVID-19 telah menyebar di seluruh Kabupaten/Kota di Propinsi Riau. Khusus di Kabupaten Rokan Hulu, tercatat sebanyak 41 kasus positif COVID-19, sebanyak 1.723 kasus suspek COVID-19 dan 1 kasus pasien COVID-19 meninggal dunia per 2 September 2020 (Riau Tanggap COVID-19, t.t).

Permasalahan yang terjadi di daerah adalah masyarakat tidak memahami ancaman COVID-19 karena penyebarannya di daerah masih dianggap kecil, sementara penyakit tersebut dapat menyebar dengan cepat dan mematikan bagi kelompok rentan. Lebih jauh lagi, Buana (2020:221) menyebutkan bahwa masyarakat Indonesia mengalami bias kognitif, yaitu gejala psikologi merasa lebih tahu, merasa dapat menjaga diri sendiri dan cenderung mengecilkan bahaya COVID-19. Protokol kesehatan sering diabaikan sementara masyarakat tetap berinteraksi satu sama lain bahkan di tempat-tempat keramaian. Sarana untuk memutus rantai penyebaran penyakit tersebut juga masih sangat terbatas. Salah satu tempat yang potensial menyebabkan kluster penyebaran COVID-19 adalah pasar.

Pasar Minggu yang berada di RT 03 RW 10 Desa Kota Tengah merupakan tempat pelaksanaan kegiatan pengabdian kepada masyarakat (abdimas) ini. Sedangkan masyarakat yang beraktifitas di pasar tersebut merupakan sasaran dari kegiatan abdimas ini. Pasar tersebut beroperasi hanya satu hari dalam seminggu, tepatnya pada hari Ahad dari pagi sampai siang hari. Dari survey yang dilakukan oleh tim pengabdi, penerapan protokol kesehatan di pasar tersebut sangat lemah dan tidak memiliki satu pun sarana pencegahan COVID-19 seperti tempat pencuci tangan. Sedangkan, spanduk himbauan penerapan protokol kesehatan hanya ditemukan di pintu masuk pasar yang berdekatan dengan jalan utama. Dengan latar belakang tersebut, kegiatan abdimas ini akan menjawab "Upaya apa yang dapat dilakukan untuk wewujudkan keamanan insani dari ancaman pandemi COVID-19 di Pasar Minggu Desa Kota Tengah?"

Kegiatan abdimas ini bertujuan untuk mewujudkan keamanan masyarakat dari ancaman COVID-19 dengan cara memutus rantai penyebarannya di daerah, khususnya di lingkungan pasar Minggu Desa Kota Tengah. Secara khusus, kegiatan ini bertujuan untuk 1) sosialisasi kewaspadaan masyarakat terhadap bahaya COVID-19; 2) mengajak masyarakat untuk menerapkan protokol kesehatan selama pandemi COVID-19 dengan disiplin; dan 3) membantu masyarakat untuk mengakses sarana pencegahan COVID-19 seperti tempat pencuci tangan. Kegiatan abdimas ini bermanfaat bagi masyarakat khususnya yang berada di lingkungan pasar dalam bentuk muculnya rasa aman dalam berinteraksi tanpa harus merasa khawatir ataupun menganggap remeh bahaya penyakit tersebut.

\section{Metode}

Kegiatan abdimas ini dilaksanakan selama dua minggu (29 Agustus - 10 Sepetember 2020), dimulai dari perencanaan, survey lapangan, pelaksaanan, evalusi dan pembuatan laporan dan luaran. Kegiatan abdimas ini dilaksanakan di Pasar Minggu RT 03 RW 10 Desa Kota Tengah Kecamatan Kepenuhan Kabupaten Rokan Hulu Propinsi Riau. Kegiatan abdimas ini dilaksanakan dalam bentuk sosialisasi dan penyediaan sarana pencegahan penyebaran COVID-19. 
Adapun gambaran tahapan dari kegiatan abdimas ini adalah sebagai berikut:

Tabel 1. Tahapan Kegiatan Abdimas

\begin{tabular}{|c|c|c|c|}
\hline \multicolumn{4}{|c|}{ Tahap Awal } \\
\hline No & Kegiatan & Tempat & Keterangan \\
\hline 1 & Perencanaan & $\begin{array}{l}\text { Daring (google } \\
\text { meet) }\end{array}$ & $\begin{array}{l}\text { Pada tahap ini, tim pengabdi mengumpulkan } \\
\text { informasi awal terkait berbagai alternatif } \\
\text { kegiatan, tempat dan sasaran. Dari berbagai } \\
\text { informasi yang telah dikumpulkan, tim } \\
\text { pengabdi memutuskan Pasar Minggu Desa } \\
\text { Kota Tengah sebagai tempat kegiatan, } \\
\text { sedangkan masyarakat yang berkunjung di } \\
\text { pasar tersebut merupakan sasaran kegiatan. } \\
\text { Tema utama dari kegiatan abdimas ini adalah } \\
\text { penyediaan sarana pencegahan COVID-19. }\end{array}$ \\
\hline 2 & Survey & $\begin{array}{l}\text { RT 03, RW } 10 \text { dan } \\
\text { Pasar Minggu Desa } \\
\text { Kota Tengah }\end{array}$ & $\begin{array}{l}\text { Tim pengabdi melakungan kunjungan kepada } \\
\text { ketua RT dan RW setempat untuk } \\
\text { memberitahukan maksud dan tujuan kegiatan } \\
\text { abdimas dan melakukan survey secara } \\
\text { langsung di Pasar Minggu Desa Kota Tengah. } \\
\text { Tim pengabdi juga menentukan lokasi-lokasi } \\
\text { yang sesuai untuk penempatan sarana yang } \\
\text { direncanakan, yaitu parkir dan pintu masuk } \\
\text { utama pasar tersebut. }\end{array}$ \\
\hline 3 & $\begin{array}{l}\text { Pengumpulan } \\
\text { alat dan } \\
\text { perlengkapan }\end{array}$ & $\begin{array}{l}\text { Kecamatan } \\
\text { Kepenuhan }\end{array}$ & $\begin{array}{l}\text { Tim pengabdi mulai mengumpulkan berbagai } \\
\text { perlengkapan seperti ember, keran, kayu, cat, } \\
\text { paku dan lainnya. Tim pengabdi juga } \\
\text { membuat disain spanduk. }\end{array}$ \\
\hline
\end{tabular}

\section{Tahap Pelaksanaan}

\begin{tabular}{|c|c|c|c|}
\hline No & Kegiatan & Tempat & Keterangan \\
\hline 1 & $\begin{array}{l}\text { Pemberian } \\
\text { informasi } \\
\text { tentang } \\
\text { bahaya dan } \\
\text { ancaman } \\
\text { COVID-19 }\end{array}$ & $\begin{array}{l}\text { Pasar Minggu Desa } \\
\text { Kota Tengah }\end{array}$ & $\begin{array}{l}\text { Kegiatan abdimas berupaya memberikan } \\
\text { informasi kepada masyarakat yang } \\
\text { berinteraksi di Pasar Minggu Desa Kota } \\
\text { Tengah tentang bahaya dan ancaman COVID- } \\
19 \text { khususnya di Kabupaten Rokan Hulu. Tim } \\
\text { pengabdi secara langsung memberikan } \\
\text { informasi tentang perkembangan COVID-19 } \\
\text { dan hal-hal yang dapat dilakukan untuk } \\
\text { memutus penyebaran penyakit tersebut } \\
\text { seperti penerapan protokol kesehatan secara } \\
\text { disiplin. }\end{array}$ \\
\hline 2 & $\begin{array}{l}\text { Pemasangan } \\
\text { spanduk } \\
\text { ajakan }\end{array}$ & $\begin{array}{l}\text { Pasar Minggu Desa } \\
\text { Kota Tengah }\end{array}$ & $\begin{array}{l}\text { Untuk memudahkan masyarakat memahami } \\
\text { maksud dari kegiatan abdimas ini, } \\
\text { pemasangan spanduk ajakan penerapan }\end{array}$ \\
\hline
\end{tabular}


penerapan

protokol

kesehatan protokol kesehatan juga dilakukan. Spanduk ajakan tersebut dipasang di pintu masuk Pasar Minggu Desa Kota Tengah agar mudah dilihat oleh masyarakat pengunjung. Ajakan tersebut dicetak dalam bahasa yang mudah dipahami seperti "Cara pencegahan Covid-19: Gunakan Masker; Jaga Jarak; Cuci Tangan Pakai Sabun."

$\begin{array}{lll}3 & \text { Pembuatan } & \text { Pasar Minggu Desa } \\ \text { tempat } & \text { Kota Tengah } \\ \text { pencuci } & \\ \text { tangan } & \end{array}$

Kegiatan pengabdian ini memberikan akses tempat pencuci tangan bagi masyarakat yang berkunjung di Pasar Minggu Desa Kota Tengah. Dengan akses sarana tersebut, masyarakat dapat berperan dalam memutus penyebaran COVID-19 untuk melindungi diri mereka sendiri dan orang lain. Tempat pencuci tangan yang dilengkapi dengan sabun dan petunjuk tentang cara cuci tangan yang benar tersebut dipasang di tempat parkir dan pintu masuk utama.

\begin{tabular}{|c|c|c|c|}
\hline \multicolumn{4}{|c|}{ Tahap Akhir } \\
\hline No & Kegiatan & Tempat & Keterangan \\
\hline 1 & Evaluasi & $\begin{array}{l}\text { Daring (google } \\
\text { meet) }\end{array}$ & $\begin{array}{l}\text { Evaluasi dilakukan untuk mengukur tingkat } \\
\text { keberhasilan pelaksanaan dengan melihat } \\
\text { target-target yang telah direncanakan. Tim } \\
\text { pengabdi telah melaksanakan semua rencana } \\
\text { kegiatan seperti sosialisasi secara langsung } \\
\text { kepada masyarakat, pemasangan } 1 \text { helai } \\
\text { spanduk dan pembuatan } 2 \text { tempat pencuci } \\
\text { tangan yang dilengkapi dengan petunjuk cara } \\
\text { cuci tangan yang benar dan sabun cair. } \\
\text { Kendala yang ditemukan oleh tim pengabdi } \\
\text { hanyalah ketidaktersediaan akses air yang } \\
\text { digunakan untuk pencuci tangan di lokasi. } \\
\text { Namun, tim pengabdi dapat menggunakan air } \\
\text { yang berasal dari rumah warga terdekat } \\
\text { dengan menggunakan kendaraan bermotor. }\end{array}$ \\
\hline 2 & $\begin{array}{l}\text { Penyusunan } \\
\text { laporan dan } \\
\text { luaran }\end{array}$ & $\begin{array}{l}\text { Daring (google } \\
\text { meet) }\end{array}$ & $\begin{array}{l}\text { Tim pengabdi menyusun laporan dan luaran } \\
\text { agar dapat disebarkan untuk mendukung } \\
\text { perkembangan ilmu pengetahuan dan } \\
\text { pelaksanaan kegiatan abdimas lainnya di masa } \\
\text { yang akan datang. Luaran yang dihasilkan dari } \\
\text { kegiatan abdimas ini meliputi pembuatan } \\
\text { media sosial, video kegiatan, pers release } \\
\text { media dan artikel jurnal. }\end{array}$ \\
\hline
\end{tabular}




\section{Hasil dan Pembahasan}

Kegiatan abdimas ini telah menghasilkan beberapa hal yang bermanfaat bagi masyarakat seperti berikut:

1. Masyarakat Pasar Minggu Kota Tengah mendapatkan informasi dari tim pengabdi terkait bahaya COVID-19 dan langkah yang dapat dilakukan untuk mencegah penyebarannya. Tim pengabdi mengajak masyarakat secara langsung seperti mengingatkan untuk memakai masker, menjaga jarak dan mengarahkan untuk mencuci tangan di tempat yang telah disediakan.

2. Pasar Minggu Kota Tengah memiliki akses tempat pencuci tangan. Sarana ini sangat dibutuhkan oleh masyarakat yang berinteraksi di pasar tersebut. Masyarakat dapat menggunakan sarana tersebut sebelum dan sesudah aktifitas jual beli. Tempat pencuci tangan dilengkapi dengan petunjuk cara cuci tangan yang benar dan sabun cair untuk membersihkan tangan dari virus.

3. Pasar Minggu Kota Tengah memiliki sarana literasi tentang penerapan protokol kesehatan. Spanduk yang dipasang berisikan ajakan agar masyarakat dapat menerapkan protokol kesehatan untuk melindungi diri sendiri dan orang lain.

4. Tim pengabdi dan pihak tempatan seperti RT dan RW memiliki hubungan yang baik melalui kegiatan abdimas khususnya dalam pencegahan penyebaran COVID19. Hubungan ini dapat dilanjutkan untuk melaksanakan kegiatan abdimas lainnya di masa yang akan datang.

Dengan pencapaian hal-hal di atas, program abdimas ini diharapkan mampu untuk mencegah penyebaran COVID-19 kluster Pasar Minggu Desa Kota Tengah. Dengan upaya pencegahan yang telah dilakukan, masyarakat di lingkungan pasar tersebut dapat merasa aman dari ancaman pandemi tersebut.

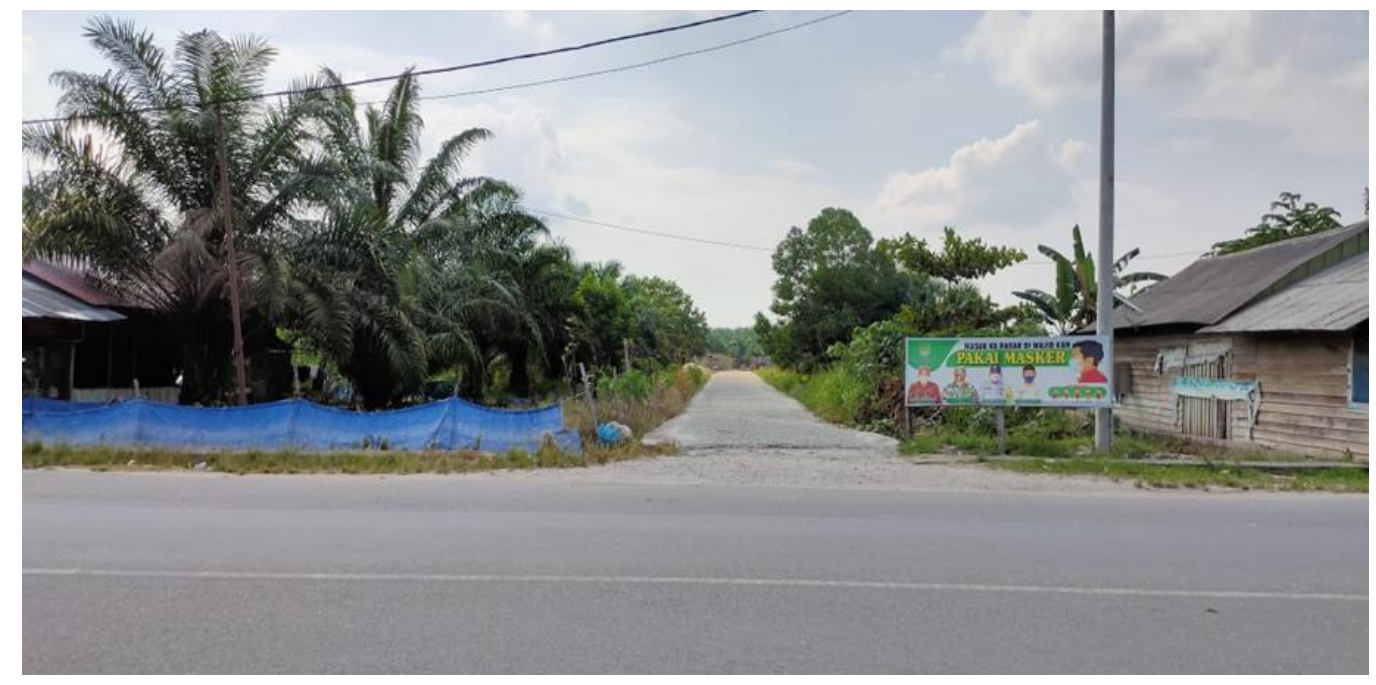

Gambar 2. Pintu Masuk Utama Pasar Minggu Desa Kota Tengah 


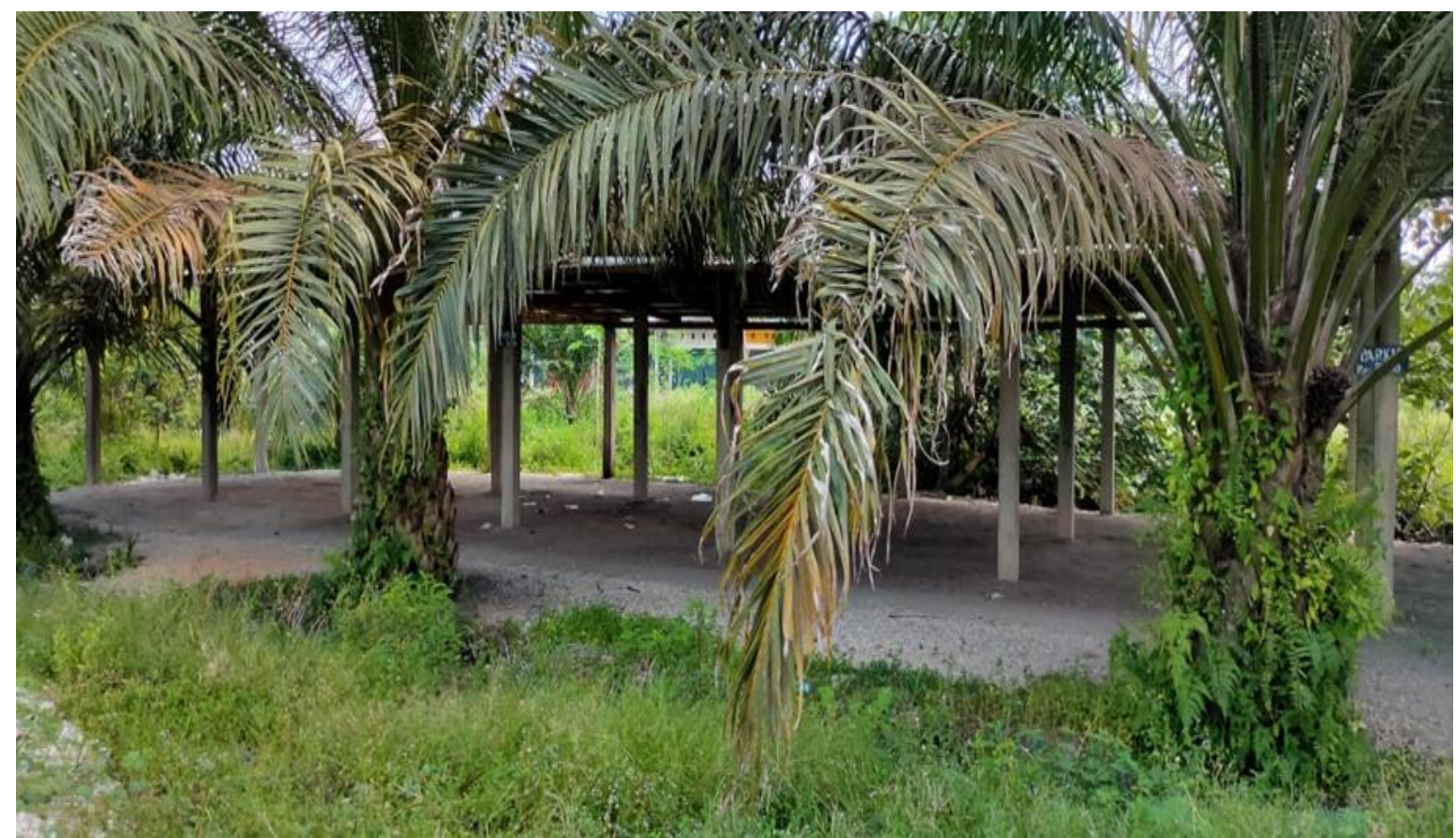

Gambar 3. Tempat Parkir Pasar Minggu (Sebelum Dilengkapi Tempat Pencuci Tangan)

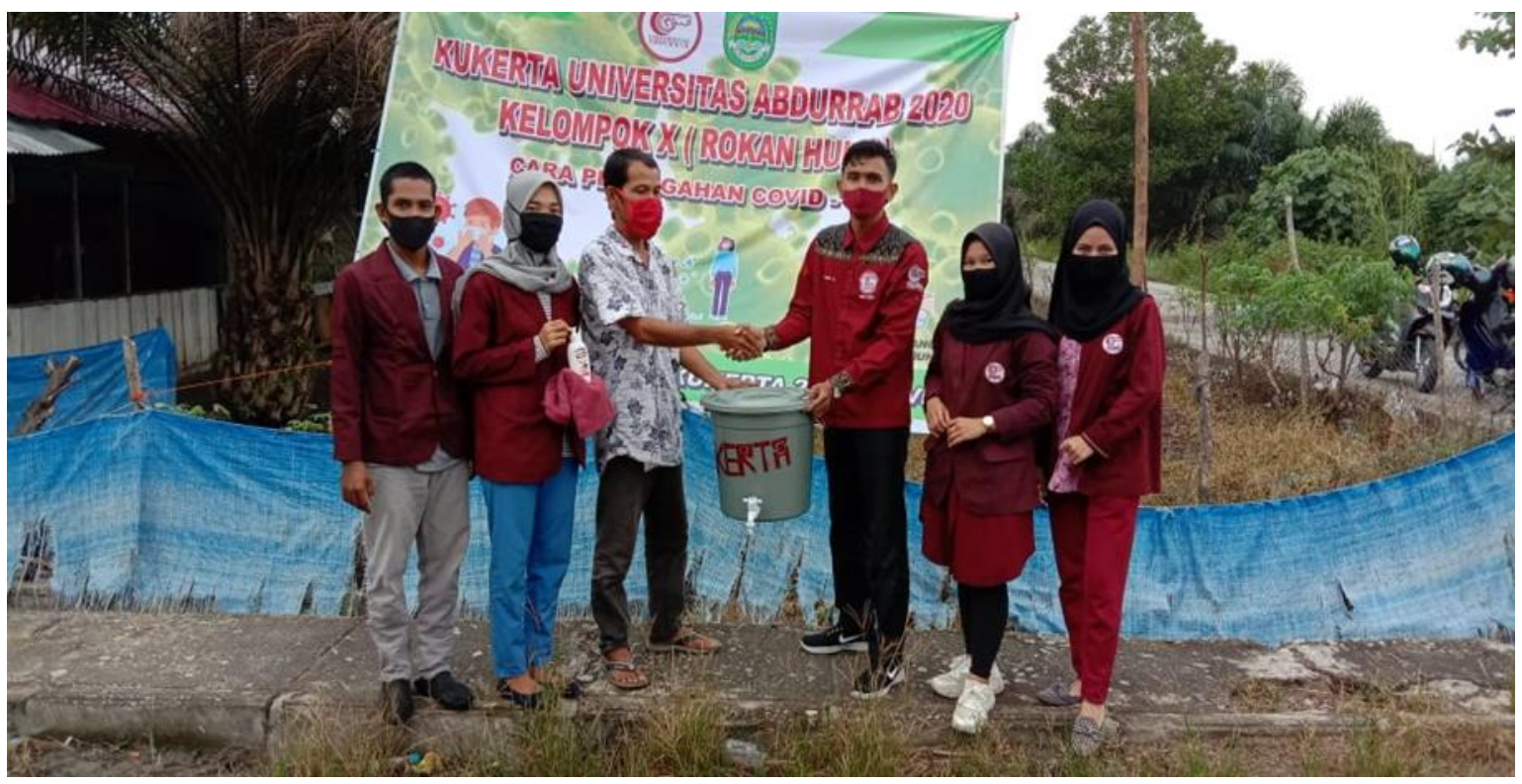

Gambar 4. Pemasangan Spanduk dan Penyerahan Simbolik Perlengkapan Pencuci Tangan 

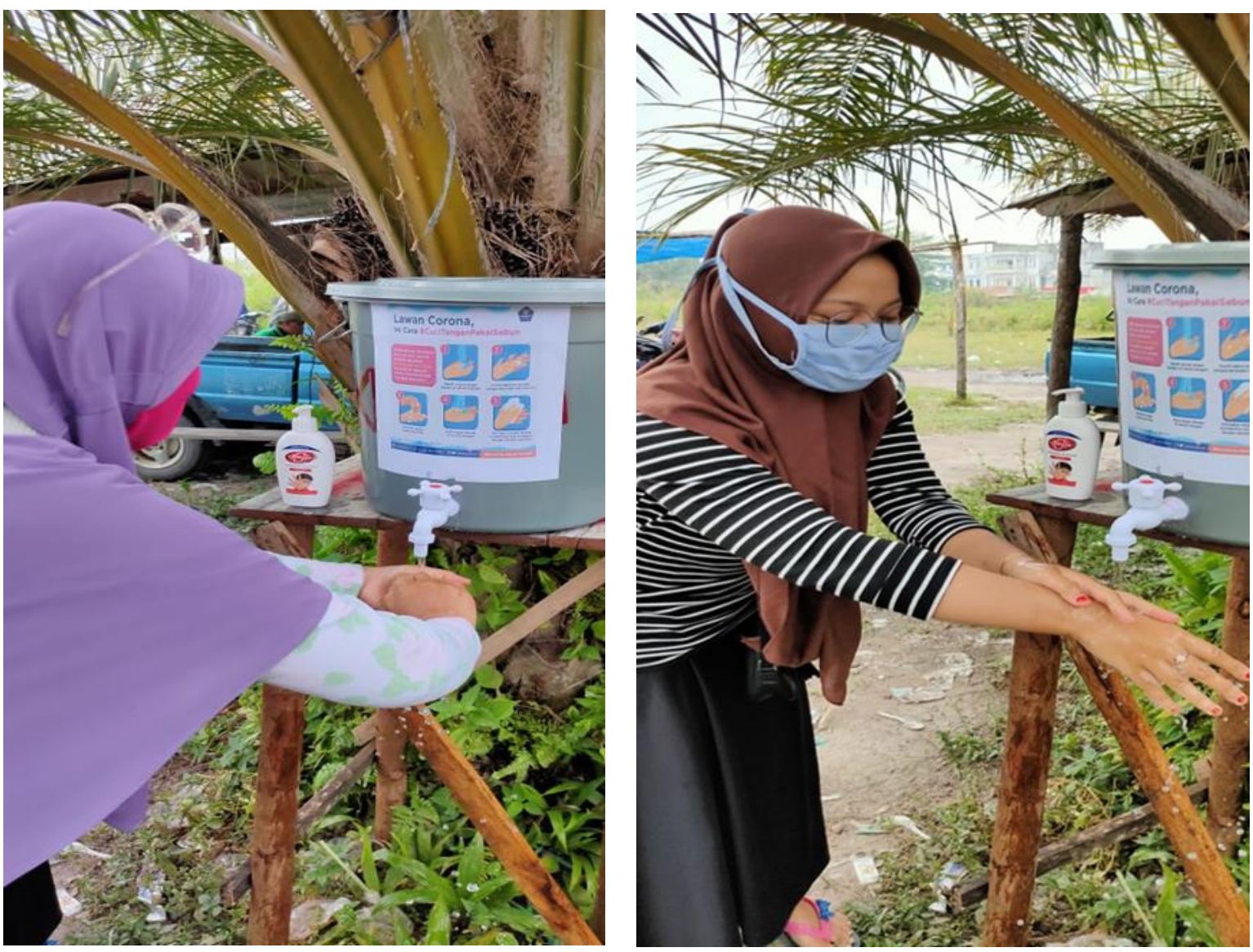

Gambar 5. Masyarakat Memanfaatkan Tempat Pencuci Tangan yang Telah Disediakan di Parkir Pasar Minggu

\section{Kesimpulan}

Secara umum kegiatan pengabdian ini berjalan dengan lancar dan disambut baik oleh RT dan RW serta masyarakat setempat. Dengan pemberian informasi tentang bahaya COVID-19 dan penerapan protokol kesehatan serta penyediaan sarana pencegahan, masyarakat dapat berperan dalam memutus penyebaran penyakit tersebut. Kegiatan abdimas ini merupakan upaya mewujudkan rasa aman bagi masyarakat dari ancaman pandemi COVID-19 dengan cara melakukan pencegahan di tengah-tengah interaksi yang sulit dihindari di lingkungan Pasar Minggu Desa Kota Tengah. Saran yang dapat diberikan setelah kegiatan abdimas ini adalah masyarakat menjaga sarana yang telah disediakan dan berkerjasama untuk saling mengingatkan untuk menerapkan protokol kesehatan khususnya di Pasar Minggu Kota Tengah.

\section{Daftar Pustaka}

Bainus, A \& Rahman, J. B. (2020). Editorial: Pandemi Penyakit Menular (COVID-19) Hubungan Internasional. Intermestic: Journal of International Studies, 4(2), 111123. DOI:10.24198/intermestic.v4n2.1 
Buana, D. R. (2020). Analisis Perilaku Masyarakat Indonesia dalam Menghadapi Pandemi Virus Corona (COVID-19) dan Kiat Menjaga Kesejahteraan Jiwa. SALAM: Jurnal Sosial \& Budaya Syar-i, 73), 217-226. DOI: 10.15408/sjsbs.v7i3.15082

Djalante, R, at al. (2020). Review and Analysis of Current Responses to COVID-19 in Indonesia: Period of January to March 2020. Progress in Disaster Science, 6, 1-9. Diperoleh dari http://dx.doi.org/10.1016/j.pdisas.2020.100091

Gugus Tugas Nasional Percepatan Penanganan COVID-19 (t.t). Hub InaCOVID-19. Diperoleh dari https://bnpb-inacovid19.hub.arcgis.com/

Lebni, J. Y, at al. (2020). How the COVID-19 Pandemic Effected Economic, Social, Political, and Cultural Factors: A Lesson from Iran. International Journal of Social Psychiatry, 1-3. DOI: 10.1177/0020764020939984

Riau Tanggap COVID-19. (t.t). Data Sebaran Suspek \& Konfirmasi COVID-19 Provinsi Riau. Diperoleh dari https://corona.riau.go.id/

Setiati, S \& Azwar, M. K. (2020). COVID-19 and Indonesia. Acta Medica Indonesiana: The Indonesian Journal of Internal Medicine, 52(1), 84-89. Diperoleh dari http://www.actamedindones.org/index.php/ijim/article/view/1426

World Health Organization. (2020). Archived: WHO Timeline - COVID-19. Diperoleh dari https://www.who.int/news-room/detail/27-04-2020-who-timeline---COVID-19 